\title{
Proteasome inhibitors act as bifunctional antagonists of human immunodeficiency virus type 1 latency and replication
}

\author{
Leia K Miller ${ }^{1,2}$, Yoshifumi Kobayashi ${ }^{1}$, Chiann-Chyi Chen ${ }^{1}$, Timothy A Russnak ${ }^{1,2}$, Yacov Ron ${ }^{1,2}$ \\ and Joseph P Dougherty ${ }^{1,2^{*}}$
}

\begin{abstract}
Background: Existing highly active antiretroviral therapy (HAART) effectively controls viral replication in human immunodeficiency virus type 1 (HIV-1) infected individuals but cannot completely eradicate the infection, at least in part due to the persistence of latently infected cells. One strategy that is being actively pursued to eliminate the latent aspect of HIV-1 infection involves therapies combining latency antagonists with HAART. However, discordant pharmacokinetics between these types of drugs can potentially create sites of active viral replication within certain tissues that might be impervious to HAART.
\end{abstract}

Results: A preliminary reverse genetic screen indicated that the proteasome might be involved in the maintenance of the latent state. This prompted testing to determine the effects of proteasome inhibitors (PIs) on latently infected cells. Experiments demonstrated that Pls effectively activated latent HIV-1 in several model systems, including primary T cell models, thereby defining Pls as a new class of HIV-1 latency antagonists. Expanding upon experiments from previous reports, it was also confirmed that PIs inhibit viral replication. Moreover, it was possible to show that Pls act as bifunctional antagonists of HIV-1. The data indicate that PIs activate latent provirus and subsequently decrease viral titers and promote the production of defective virions from activated cells.

Conclusions: These results represent a proof-of-concept that bifunctional antagonists of HIV-1 can be developed and have the capacity to ensure precise tissue overlap of anti-latency and anti-replication functions, which is of significant importance in the consideration of future drug therapies aimed at viral clearance.

Keywords: HIV-1, Viral latency, Viral replication, Proteasome inhibitors, Antiviral, Bifunctional

\section{Background}

Human immunodeficiency virus type 1 (HIV-1) infection is presently incurable necessitating life-long drug treatment [1]. HIV-1 is able to persist within its cellular host by entering a reversible dormant state, termed latency, which provides protection from the immune system and antiviral pharmaceuticals. Consequently, latent HIV-1 is able to persist indefinitely awaiting activation, upon which it can reestablish a productive infection in the

\footnotetext{
* Correspondence: doughejp@rwjms.rutgers.edu

'Department of Molecular Pharmacology, Rutgers, The State University of New Jersey - Robert Wood Johnson Medical School, 675 Hoes Lane, Piscataway, NJ 08854, USA

${ }^{2}$ Microbiology and Molecular Genetics Graduate Program, Graduate School of Biomedical Sciences, Rutgers, The State University of New Jersey, New
} Brunswick, NJ, USA

\section{Biomed Central}

(c) 2013 Miller et al.; licensee BioMed Central Ltd. This is an open access article distributed under the terms of the Creative Commons Attribution License (http://creativecommons.org/licenses/by/2.0), which permits unrestricted use, distribution, and reproduction in any medium, provided the original work is properly cited. absence of highly active antiretroviral therapy (HAART) (Latency Reviewed in [2]).

Currently, one strategy to abolish latent infection involves treating patients with a latency antagonist concomitantly with HAART to prevent new infections and the reestablishment of the latent reservoir upon the activation of latent virus [2-8]. A major reservoir of latent infection in vivo is within memory $\mathrm{CD}^{+} \mathrm{T}$ cells, [9] although other cell types have been reported to harbor latent HIV-1, including cells of myeloid origin. Importantly, latently infected cells can be found in tissues that are resistant to effective penetration of at least some HAART drugs [10-17]. For instance, the brain was reported to house latently infected cells [10,17-21] yet the blood-brain barrier (BBB) can restrict the penetrance of 
some antiretroviral drugs into the brain [22-28]. In light of this, it may be important to not only treat patients with both latency activators and HAART simultaneously, but to ensure their concurrent delivery to the same tissue and cellular compartments.

The 26S proteasome is composed of two regulatory $19 S$ subunits that abut a catalytic 20S core subunit and as a whole is responsible for the degradation of ubiquitinated proteins in the cell [29]. Interestingly, the proteasome is involved in promoting HIV-1 replication via its specific degradation of the APOBEC3 family of HIV-1 restriction factors in the presence of the viral protein Vif (Reviewed in [30,31]). Surprisingly, as delineated in this study, it was also found that the proteasome is involved in maintaining HIV-1 latency. The fact that the proteasome positively influences both HIV-1 replication and latency makes it a unique drug target whose inhibition has the potential to elicit dual antiviral effects. The development of a drug that exhibits bifunctional antagonism of both aspects of the viral life cycle would help to address concerns regarding the insufficient penetration of HAART into some tissues harboring latently infected cells.

In this report, evidence that proteasome inhibitors (PIs) hinder both HIV-1 latency and replication is presented. Here, it is shown that PIs activate latent HIV-1 in several in vitro model systems, including two primary human $\mathrm{CD}^{+} \mathrm{T}$ cell model systems. Consequently, PIs represent a new class of HIV-1 latency antagonists. Additionally, this study confirms that PIs inhibit HIV-1 infectivity. Finally, it is demonstrated that PIs antagonize both HIV-1 latency and replication in a sequential manner in virus-producing cells. These results introduce a novel proof-of-concept that effective bifunctional HIV-1 antagonists can be developed.

\section{Results}

PIs activate latent HIV-1 transcription, gene expression, and virus production

A preliminary reverse genetic screen in a HeLa cell model of HIV-1 latency implicated the $26 \mathrm{~S}$ proteasome as a novel cellular regulator of the maintenance of HIV1 latency (unpublished data). As the involvement of the proteasome in the maintenance of latency was unexpected, we chose to further validate its role through the use of PIs. Latently infected cells were treated with PIs to analyze the activation of proviral transcription. OM-10.1 cells, which are a clonal population of HL-60 promyelocytes that are latently infected with the replicationcompetent HIV-1 $1_{\text {LAV }}$ strain [32-36], were treated with the PI Velcade. Velcade is an inhibitor of the chymotrypsinlike activity of the $20 \mathrm{~S}$ proteasome core particle $[37,38]$ and is also FDA approved for the treatment of multiple myelomas, leukemias, and lymphomas [37,39-42]. Velcade inhibited proteasome function within two hours (Figure 1A), and resulted in a significant increase in the level of nefcontaining viral RNAs in OM-10.1 cells as early as 12 hours post-treatment (Figure 1B). To confirm the activation of latent viral transcription, two additional inhibitors of the chymotrypsin-like activity of the proteasome (clasto-Lactacystin $\beta$-lactone (CLBL) and MG-132 [37,38]) were used to assess the accumulation of both nef- and env-containing viral RNAs. CLBL and MG-132 also inhibited proteasome function within two hours (Figure 1A) and significantly induced the expression of viral RNAs (Figure 1C and D). Of note, concentration dependence is shown for Velcade due to its clinical relevance. Otherwise, optimal PI concentrations were selected and utilized based on knowledge of $\mathrm{IC}_{50}$ concentrations as well as cytotoxicity and dose response profiles (data not shown).

Next, OM-10.1 cells and additional tissue culturebased latency model systems (HeLa\#14 cells [43] and 24ST1NLESG cells [44]) were treated with PIs to analyze the activation of proviral gene expression and virus production. HeLa\#14 cells are a clonal population of HeLa cells that are latently infected with an $\mathrm{HIV}-1_{\mathrm{NL} 4-3}$-based reporter construct RLUC/RFP. Briefly, the vector is rendered replication-incompetent via deletions in pol and env while red fluorescence protein (RFP) is expressed as an early gene product from the nef position and Renilla luciferase (RLUC) is expressed as a late gene product from the env position (Figure 2A) [43]. 24ST1NLESG cells are a clonal population of SupT1 cells, a human $\mathrm{CD}^{+} \mathrm{T}$ cell line, latently infected with an $\mathrm{HIV}-1_{\mathrm{NL} 4-3^{-}}$ based reporter construct SEAP/GFP. Briefly, the vector is rendered replication-incompetent via deletions in pol and env while green fluorescence protein (GFP) is expressed as an early gene product from the nef position and secreted alkaline phosphatase (SEAP) is expressed as a late gene product from the env position (Figure 2B) [44]. All three PIs were able to significantly induce HeLa\#14 cell RLUC expression (Figure 2C), 24ST1NLESG cell SEAP expression (Figure 2D), as well as induce viral particle production from OM-10.1 cells, as evidenced by a significant increase in HIV-1 capsid protein (p24) concentration in the supernatant (Figure 2E). Again, PI concentrations and treatment durations were selected and utilized based on knowledge of $\mathrm{IC}_{50}$ concentrations as well as cytotoxicity and dose response profiles (data not shown). It should be noted that although the expression of RLUC in HeLa\#14 cells treated with DMSO appears to be high, it does not indicate that DMSO activates latent HIV-1 gene expression, as the magnitude of RLUC expression is equivalent in untreated HeLa\#14 cells cultured for 48 hours in a small-well format (data not shown). Despite this relatively high background, PIs significantly induce RLUC expression in these cells (greater than 5-fold) over DMSO. 

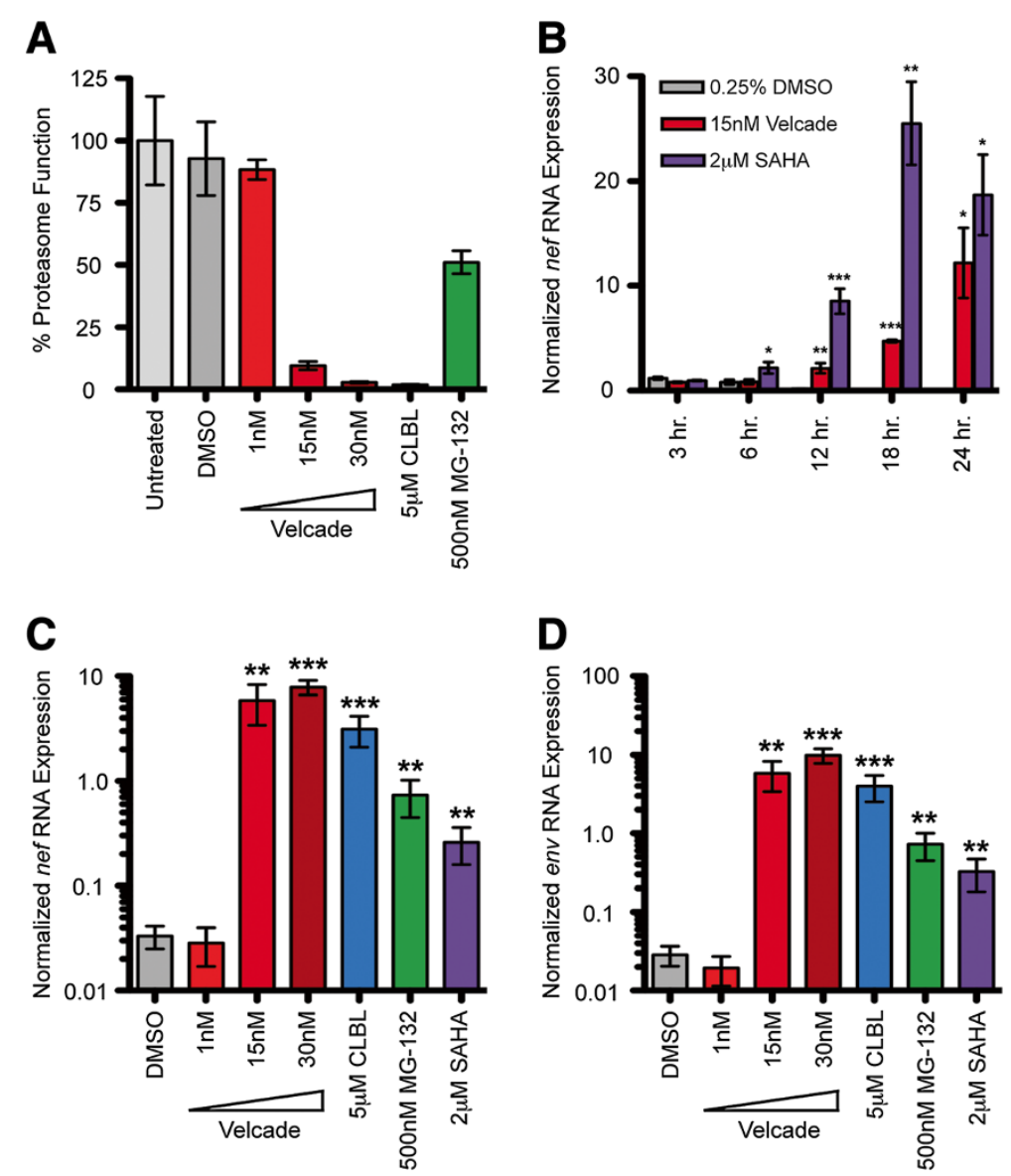

Figure 1 PIs activate latent HIV-1 transcription. A. OM-10.1 cells were treated with PIs as indicated and proteasome activity was assessed two hours post-treatment. The values shown specify the percent proteasome function compared to untreated cells, whose function was set to $100 \%$. B. OM-10.1 cells were treated with 15nM Velcade for the indicated time course. At each time point, nef RNA levels were analyzed via reverse transcription-quantitative PCR. RNA expression values were calculated via $\triangle \triangle C(\mathrm{t})$ method with the values normalized to the expression level of GAPDH in each sample. C. OM-10.1 cells were treated with PIs as indicated and nef RNA and D. env RNA levels were analyzed 72 hours posttreatment via reverse transcription-quantitative PCR (values calculated as above). Error bars indicate SEM. Asterisks indicate a significant difference ( $\left.{ }^{*} p<0.05 ;{ }^{* *} p<0.01 ;{ }^{* * *} p<0.001\right)$ in RNA expression levels between drug-treated cells and DMSO-treated (negative control) cells. P-values calculated using one-tailed Student's $t$ test. Cells were treated with SAHA as a positive control. Velcade was used in three different concentrations where indicated to illustrate concentration dependence. The figure represents average values from three independent experiments.

The effects of proteasome inhibition on proviral gene expression in two latent HIV-1 primary human $\mathrm{CD}^{+} \mathrm{T}$ cell models were also studied. To start, HIV-1 virions were produced using a replication-incompetent $\mathrm{HIV}-1_{\mathrm{NL4}-3^{-}}$ based reporter construct gGn $\Delta$ in which Gaussia luciferase (GLUC) and GFP are expressed as early gene products from the nef position (Figure 3A). This reporter virus was then used to establish a latent HIV-1 infection in primary human $\mathrm{CD}^{+} \mathrm{T}$ cells, isolated from peripheral blood mononuclear cells (PBMCs) collected from healthy donors, via two distinct methods. The first involved the infection of non-polar $\mathrm{CD} 4^{+} \mathrm{T}$ cells, which are considered to be the in vitro counterparts of latently infected central memory $\mathrm{T}$ cells in vivo [45]. Naïve human $\mathrm{CD}^{+} \mathrm{T}$ cells were isolated, activated in a non-polarizing environment, infected with the gGn $\Delta$ virus, and then cultured for seven days to establish a latent infection. These cells are referred to as $\mathrm{T}_{\mathrm{CM}^{-}}$-like cells [45]. The second method involved the use of primary human $\mathrm{CD} 4^{+} \mathrm{T}$ cells transduced with a $B C L 2$ expression vector, which mimic both central memory and effector memory $\mathrm{T}$ cells [46]. The BCL2transduced cells were activated, infected with the gGn $\Delta$ virus, and cultured for seven days to permit the establishment of viral latency [46]. The latently infected $\mathrm{T}_{\mathrm{CM}^{-}}$ like primary and $B C L 2$-transduced human $\mathrm{CD} 4^{+} \mathrm{T}$ cells were treated with PIs and analyzed for latent viral gene expression 48 hours later. Despite the expected donorto-donor variability, MG-132 and Velcade treatments significantly induced the expression of GFP (Figure 3B and $\mathrm{C}$ ) in both latent, primary human $\mathrm{CD}^{+} \mathrm{T}$ cell models. It should be noted that CLBL caused significant cytoxicity in both of these primary cell model systems, 


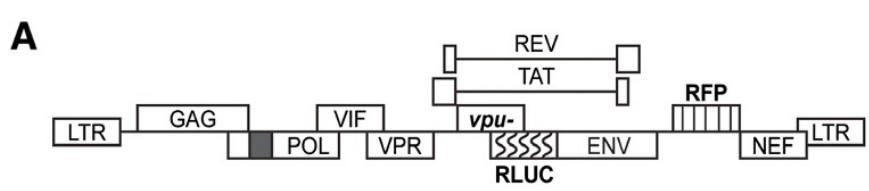

B

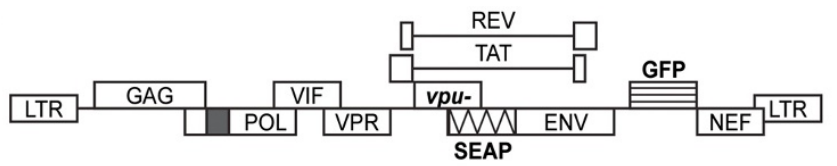

C

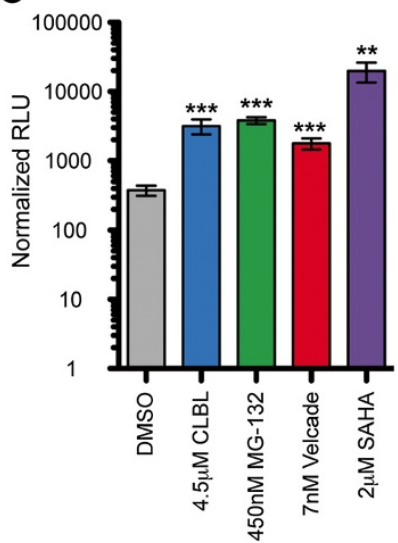

D

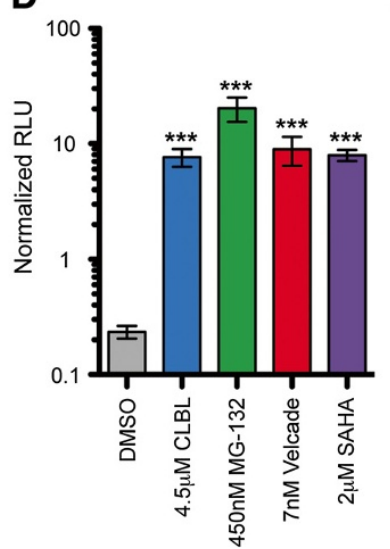

E

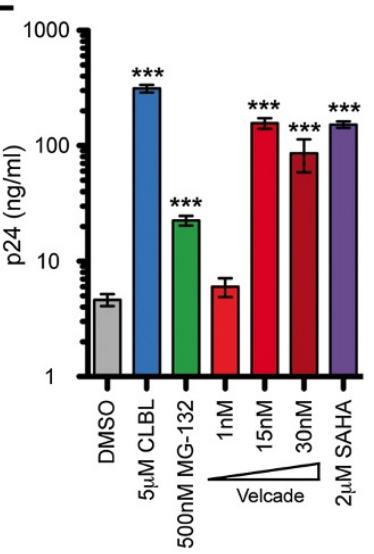

Figure 2 PIs activate latent HIV-1 gene expression in tissue culture model systems. A. Schematic of the RLUC/RFP construct used to establish latently infected HeLa\#14 cells. The vpu gene start codon is mutated for robust reporter gene expression. The black box represents a deletion and the patterned boxes represent RLUC and RFP reporter gene insertions. Together, the deletion in pol and the insertion in env render the vector replication-incompetent. B. Schematic of the SEAP/GFP construct used to establish latently infected 24ST1NLESG cells. The vpu gene start codon is mutated for robust reporter gene expression. The black box represents a deletion and the patterned boxes represent SEAP and GFP reporter gene insertions. Together, the deletion in pol and the insertion in env render the vector replication-incompetent. C. HeLa\#14 cells were treated for 48 hours with PIs as indicated and RLUC activity was measured. The values shown indicate RLUs normalized to protein concentrations. D. 24ST1NLESG cells were treated with CLBL for 48 hours and MG-132 and Velcade for 72 hours at the indicated concentrations, and SEAP activity was analyzed. The values shown indicate RLUs normalized to the number of live cells. E. OM-10.1 cells were treated for 72 hours with PIs as indicated and p24 levels in the supernatant were analyzed via p24 ELISA. p24 levels (ng/mL) were calculated using standard curve values. Error bars indicate SEM. Asterisks indicate significant differences (** $\left.p<0.01 ; *^{* *} p<0.001\right)$ between drug-treated cells and DMSOtreated (negative control) cells. P-values were calculated using one-tailed Student's t test. Cells treated with SAHA served as positive controls. The figure represents average values from three independent experiments.

which made it difficult to assess the latency antagonist effect of CLBL here. However, the cytotoxic effects of CLBL were much less pronounced in the tissue culture model systems tested in which CLBL significantly activated latent virus. Overall, two of the three PIs clearly activated latent virus in the two primary cell models tested, and all three PIs activated latent virus in the three tissue culture model systems tested. These results strongly suggest that PIs act as latency antagonists.

We also examined the activation status of uninfected primary human resting $\mathrm{CD} 4^{+} \mathrm{T}$ cells following exposure to MG-132 and Velcade. Resting human $\mathrm{CD}^{+}{ }^{+} \mathrm{T}$ cells cultured in the presence of Velcade or MG-132 for 48 hours did not become activated, as evidenced by a lack of expression of the $\mathrm{T}$ cell activation marker CD25 (Figure 3D). These results are in concert with previous studies, which indicated that PIs do not activate primary human $\mathrm{T}$ cells $[47,48]$.

\section{Pls decrease viral titers and inhibit HIV-1 infectivity}

Previous reports indicate that proteasomal inhibition in producer cells decreases HIV-1 titers and virion infectivity [49-53]. To confirm the findings, virions were generated via transfection of the replication-competent $\mathrm{HIV}-1_{\mathrm{NL4}-3^{-}}$ based reporter construct $\mathrm{Gn}$, in which GFP is expressed as an early gene product from the nef position, (Figure 4A) into HEK293T cells. The reporter virus was used to infect activated primary human $\mathrm{CD} 4^{+} \mathrm{T}$ cells isolated from PBMCs collected from healthy donors. Six hours postinfection, cells were either treated with $10 \mathrm{nM}$ Velcade or left untreated for 72 hours. The resultant virus-containing supernatants were collected and p24 concentrations were measured. As shown in Figure 4B, supernatant collected 
A

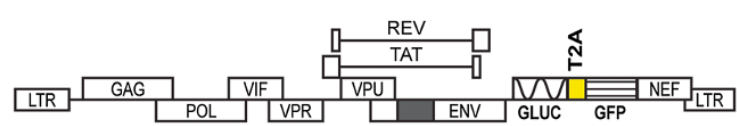

B

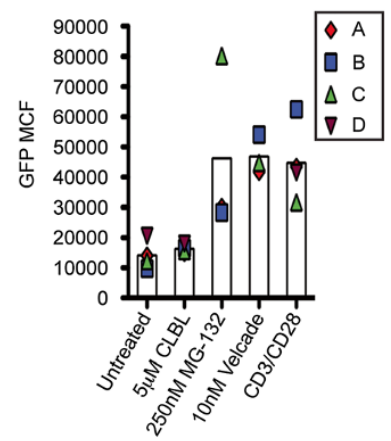

C

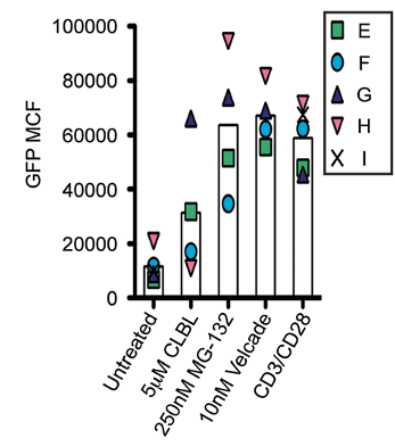

D

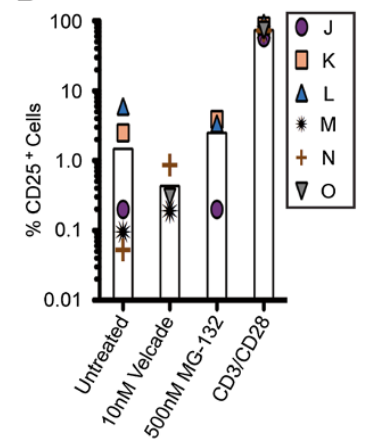

Figure 3 Pls activate latent HIV-1 gene expression in primary $\mathrm{CD}^{+} \mathrm{T}$ cell models. A. Schematic of gGn $\Delta$ construct used to establish latently infected $T_{C M}$-like and BCL2-transduced cells. Black box represents a deletion in env, which renders this construct replication-incompetent. Patterned boxes indicate GLUC and GFP reporter gene insertions. The yellow box specifies a T2A sequence, which directs bicistronic expression [88,89]. B. TCM ${ }^{-}$ like cells and C. BCL2-transduced primary CD4 ${ }^{+} T$ cells were treated for 48 hours with Pls as indicated. Flow cytometry was performed and the values shown indicate GFP mean channel fluorescence (MCF). All cells treated with PIs were simultaneously treated with Raltegravir to prevent the integration of as yet unintegrated viral genomes. MG-132 and Velcade treatments significantly activated latent virus in both $T_{C M}$-like cells $(p<0.05 ; p<0.001$, respectively) and in BCL2-transduced cells ( $p<0.01 ; p<0.001$, respectively) in comparison to untreated (negative control) cells. P-values calculated using

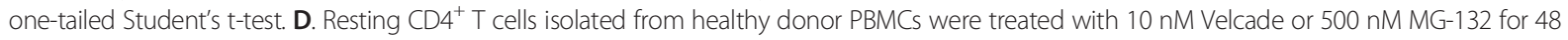
hours and then incubated with FITC-conjugated CD25 antibody. The percentage of CD25 cells in each sample was determined via flow cytometry. In all experiments, the vertical open bars represent average values from all healthy donors while symbols represent individual donor results; each donor result represents a singlicate experiment. Cells treated with CD3/CD28 activating beads served as positive controls.

from untreated virus-producing cells contained approximately $30 \%$ more p24 than supernatant collected from Velcade-treated virus-producing cells indicating that PIs reduce viral output. To analyze infectivity, the viral supernatants were used to infect HeLaT4 cells. As a control for potential effects on viral infectivity arising from residual PI in the inoculums collected from PI-treated virusproducing cells, $10 \mathrm{nM}$ Velcade was added to some HeLaT4 cells as they were infected with inoculums collected from untreated virus-producing cells. Forty-eight hours post-infection, the number of infected $\left(\mathrm{GFP}^{+}\right)$ HeLaT4 cells were counted and normalized to the p24 concentrations of inoculating viral supernatants. In a single round of infection, virus collected from infected, Velcade-treated primary $\mathrm{CD}^{+}{ }^{+} \mathrm{T}$ cells [PI (virus)] was only able to infect approximately one fourth the number of HeLaT4 cells as virus collected from infected, untreated primary $\mathrm{CD}^{+}{ }^{+} \mathrm{T}$ cells (Figure $4 \mathrm{C}$ ). The addition of Velcade to HeLaT4 cells at the time of infection [PI (target)] did not have an effect on viral infectivity suggesting that residual PI in the inoculum collected from PI-treated virus-producing cells is not responsible for the reduction in infectivity observed. These results also suggest that PIs reduce viral output and virion infectivity when added to virus-producing cells but do not inhibit the infection of PI-treated target cells. This is in agreement with previous findings [51-54].

\section{PIs are bifunctional antagonists of HIV-1}

The results demonstrating that PIs can activate latent HIV-1, reduce viral output, and inhibit HIV-1 infectivity suggested the feasibility of antagonizing both latency and replication using a single pharmaceutical. To test this, OM-10.1 cells were treated with the PI CLBL to analyze the infectivity of virions following the activation of latent HIV-1. OM-10.1 cells were treated with either TNFo, to stimulate the production of positive control virus, or with CLBL, to stimulate the production of virus under the influence of proteasome inhibition (CLBL was chosen as it is the most potent activator of virus production in OM-10.1 cells and is therefore more comparable to TNF $\alpha$ than the other PIs). Seventy-two hours posttreatment, virus-containing supernatants were collected and p24 concentrations were measured. Figure 5A illustrates the magnitude of the induction of $\mathrm{p} 24$ production observed following the treatment of OM-10.1 cells with these two activators. Due to the fact that TNF $\alpha$ induces a significantly higher titer of virus than CLBL, viral supernatants were diluted to equal p24 concentrations and then used to infect U373-MAGI-CXCR4 $4_{\text {CEM }}$ cells to analyze viral infectivity. U373-MAGI-CXCR4 $4_{\text {CEM }}$ cells are human glioblastoma cells that have been transduced to constitutively express CD4 and CXCR4. Additionally, they express $\beta$-Galactosidase ( $\beta$-Gal) from an HIV-1 LTR promoter (Tat-inducible expression) and as such, 


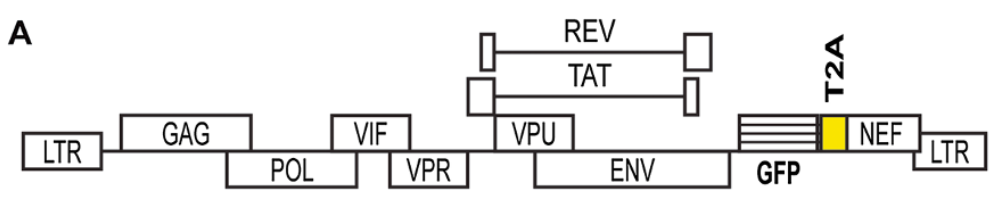

B

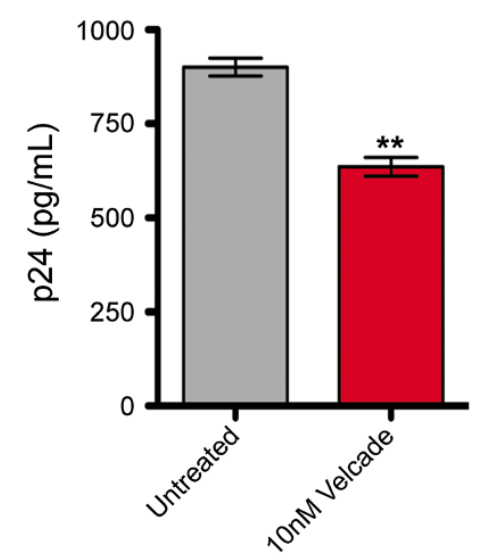

C

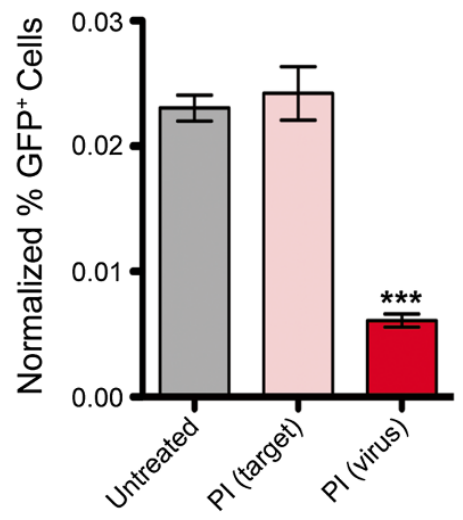

Figure 4 Primary $\mathrm{CD}^{+} \mathrm{T}$ cells treated with Velcade produce fewer, less infectious virions. A. Schematic of $\mathrm{Gn}$ construct used to produce replication-competent virus for this experiment. The patterned box indicates GFP reporter gene insertion and the yellow box specifies a T2A sequence, which directs bicistronic expression [88,89]. B. CD4 ${ }^{+}$T cells isolated from healthy donor PBMCs were activated and infected with Gn virus. Six hours post-infection, cells were either treated with $10 \mathrm{nM}$ Velcade or left untreated as a positive control. Seventy-two hours postinfection, virus-containing supernatants were collected and p24 levels were analyzed via p24 ELISA. Values shown represent p24 levels (pg/mL) calculated using standard curve values. C. Untreated and Velcade-treated virus containing supernatants were used to infect HeLaT4 cells. Untreated supernatants were also used to infect HeLaT4 cells in the presence of 10nM Velcade [PI (target)] to control for effects that may arise from residual Velcade in the inoculum collected from Velcade-treated virus producing cells [PI (virus)]. Forty-eight hours post-infection, GFP ${ }^{+}$cell numbers were analyzed via flow cytometry. Values shown indicate percent GFP ${ }^{+}$cells normalized to the p24 (ng/ml) concentration of the inoculating viral supernatant. Error bars indicate SEM. Asterisks indicate significant differences $\left({ }^{* *} p<0.01 ;{ }^{* * *} p<0.001\right)$ between Velcade treatments and untreated (positive control) cells. P-values calculated using one-tailed Student's $t$ test. The figure represents average values from three independent experiments, each of which utilized primary cells isolated from different healthy donors.

are regularly used to obtain HIV-1 titers [55]. Fortyeight hours post-infection, we analyzed $\beta$-Gal activity in infected cell lysates. As shown in Figure 5B, cells infected with virions produced from CLBL-stimulated OM-10.1 cells expressed five times less $\beta$-Gal than cells infected with the same amount of virions produced from TNF $\alpha$-stimulated cells, indicating that virus produced from PI-treated cells exhibit reduced infectivity. Additionally, these results corroborate the data presented in Figure 4. These experiments delineate the ability of PIs to both activate latent virus in a population of cells and inhibit the replication of resulting virus from that population of cells within a treatment duration of only three days. Therefore, it is expected that continuous PI treatment over several rounds of infection would result in an exponential decline in both latent and replicating HIV-1.

\section{Discussion}

This report demonstrates that PIs have the ability to activate latent HIV-1 in three tissue culture model systems and two primary cell model systems, and thereby identifies PIs as a new class of HIV-1 latency antagonists. We have also confirmed that proteasome inhibition in producer cells results in reduced viral titers and the production of virions that exhibit reduced infectivity. Taken together, our results represent a novel proof-of-concept that a single pharmaceutical drug can antagonize both HIV-1 latency and replication simultaneously.

The identification of the proteasome as a potential cellular regulator of the maintenance of HIV-1 latency, from our preliminary genetic screen (unpublished data), was initially surprising considering that proteasome activity is involved in the activation of $\mathrm{NFKB}_{\mathrm{K}}$, a transcription factor known to potently activate HIV-1 transcription (Reviewed in [56]). However, a review of the literature revealed two gene expression profile studies that supported this finding. One study analyzed the gene expression profile in latently infected $\mathrm{ACH}-2$ cells and found that 15 proteasome genes were upregulated in the latent state prior to viral reactivation [57]. The other study, which analyzed gene expression profiles in productively infected and latently infected cells, found that seven proteasome genes were downregulated in productively infected $\mathrm{H} 9$ cells in comparison to uninfected cells [58]. This information, in 


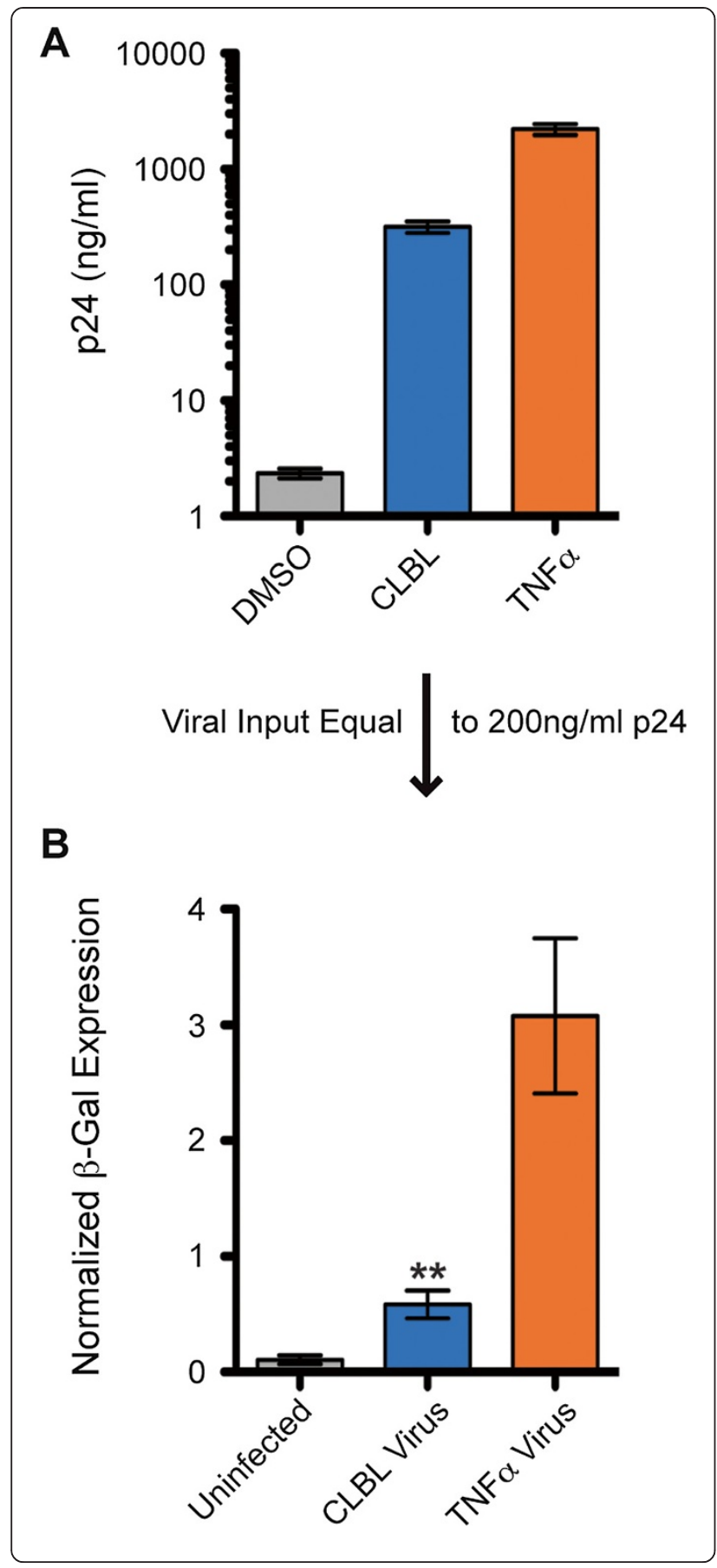

Figure 5 HIV-1 virions produced via PI-mediated activation of latent virus exhibit reduced infectivity. A. OM-10.1 cells were treated with $50 \mathrm{ng} / \mathrm{ml}$ TNFa to stimulate the production of positive control viral particles, with $5 \mu \mathrm{M} C L B L$ to stimulate the production of viral particles under the influence of proteasome inhibition or with DMSO as a negative control. Seventy-two hours post-treatment, viral supernatants were collected and p24 levels were analyzed via p24 ELISA. Values shown represent p24 levels $(\mathrm{ng} / \mathrm{mL})$ calculated using standard curve values. B. CLBL and TNFa treated virus-containing supernatants were diluted to a p24 concentration of $200 \mathrm{ng} / \mathrm{ml}$ and used to infect U373-MAGI-CXCR4 $4_{\text {CEM }}$ cells. Forty-eight hours postinfection, $\beta$-Gal expression was quantified using the $\beta$-Gal Enzyme Assay System (Promega, Madison, WI) and standard curve values. Numbers depict $\beta$-Gal expression normalized to protein concentrations. Error bars indicate SEM. Asterisks indicate a significant difference $(p<0.01)$ in $\beta$-Gal expression between cells infected with TNFa treated virus and CLBL treated virus. P-value was calculated using one-tailed Student's $t$ test. Results represent average values from three independent experiments.

accordance with our preliminary results, led us to formulate the hypothesis that the proteasome is involved in maintaining HIV-1 latency. Indeed, as shown in Figures 1, 2 , and 3, inhibiting the proteasome significantly activated latent viral transcription in OM-10.1 cells as well as latent viral gene expression in all tissue culture and primary cellbased HIV-1 latency models tested. There is one study that seemingly contradicts our findings that PIs activate latent proviral transcription in which it was reported that PIs downregulate HIV-1 LTR-dependent gene expression [52]. However, their results were obtained from experiments in which luciferase expression was analyzed in cells that had been transiently co-transfected with pLTR-LUC and a p65 overexpression plasmid (to induce LUC expression) 32 hours prior to the addition of PIs. In that scenario, luciferase transcription was initiated prior to the addition of PIs and therefore, their results do not reflect a PI-mediated effect on transcriptional initiation. Our studies indicate that PIs induce the initiation of latent proviral transcription, which then results in an upregulation of gene expression. Also, our results were obtained from experiments utilizing fully integrated, latent HIV-1, which is a more relevant system for analyzing the regulation of LTR-driven gene expression.

The variability in the degree of activation of viral transcription and gene expression between all inhibitors and all model systems in the current study could be attributed to differences in toxicities and pharmacokinetics associated with each drug within each model system. Variability might also be affected by the specific model system and mode of reporter gene analysis. For example, late gene products were analyzed in the tissue culture model systems (RLUC and SEAP) while an early gene product was analyzed in the primary cell model systems (GFP). In addition, a degree of variability is expected when comparing results in primary cells obtained from 
different donors $[59,60]$. Nevertheless, PIs significantly activated latent virus in all five model systems tested and therefore, the results identify PIs as a new, potent class of HIV-1 latency antagonists. The primary latent cell models in this study were utilized instead of cells directly isolated from HIV-1 infected patients for a specific reason. Generally, when using patient samples for latency activation studies, the addition of allogeneic, MHC mismatched $\mathrm{CD}^{+}{ }^{+} \mathrm{T}$ cells is required to allow viral outgrowth upon latent viral reactivation [4,61-64]. The addition of allogeneic cells themselves might contribute to the activation of latent virus in patient sample systems and therefore, the latently infected primary cell models, described in the results section, were chosen for testing the antagonist activity of PIs.

It is of note that we were able to confirm previous findings $[47,48]$ that PIs do not activate primary human resting $\mathrm{CD}^{+} \mathrm{T}$ cells in vitro (Figure $3 \mathrm{D}$ ). This is an important consideration with any potential latency antagonist in order to avoid promoting a "cytokine storm" during treatment. In corroboration, studies have indicated that PIs are not prohibitively toxic in vivo, as the PI Velcade is FDA approved for the treatment of multiple myelomas, leukemias, and lymphomas [37,39-42].

There are potential explanations for PI-mediated activation of latent HIV-1. First, there is increasing evidence that the $26 \mathrm{~S}$ proteasome and/or individual $19 \mathrm{~S}$ and $20 \mathrm{~S}$ proteasome subparticles can regulate transcription both proteolytically and non-proteolytically [65]. Interestingly, a study found that the $26 \mathrm{~S}$ proteasome is associated with the HIV-1 LTR and controls basal transcription proteolytically in the absence of Tat in HeLa-LTR-Luc cells $[66,67]$. Therefore, it is possible that PIs facilitate the activation of latent HIV-1 by inhibiting the degradation of factors that are involved in promoting viral transcription. For example, it was recently shown that the proteasome partially downregulates the expression of Cyclin T1, a subunit of the P-TEFb complex, in resting memory human $\mathrm{CD}_{4}^{+} \mathrm{T}$ cells [68]. The P-TEFb complex is essential for HIV-1 transcriptional elongation as a cofactor of Tat (Reviewed in [56]). It is theorized that low levels of Cyclin $\mathrm{T} 1$ contribute to the establishment of latency in resting memory $\mathrm{CD}^{+} \mathrm{T}$ cells because they are less capable of supporting processive viral transcription [68]. Hence, PIs might promote the activation of latent HIV-1 transcription by stabilizing the Cyclin T1 component of the $\mathrm{P}$-TEFb complex. It will be of interest to explore the mechanism(s) of PI-induced activation of latent HIV-1 in more detail.

Experiments were also performed indicating that PIs inhibit HIV-1 replication by reducing viral output and virion infectivity (Figures 4 and 5). These findings corroborate previous reports. One report found that the PI Lactacystin reduced viral release from cells transfected with HIV-1 $1_{\mathrm{NL} 4-3}$ by approximately 3 -fold. Moreover, they found that MG-132 decreased the infectivity of virions released from treated, HIV-1 $1_{\mathrm{NL} 4-3}$ infected human A3.01 $\mathrm{T}$ cells by 50 -fold. It should be noted that the concentration of MG-132 used in that study was 100 times higher (40-50 $\mu \mathrm{M})$ than the concentration used here, which could explain the fact that they observed a much higherfold reduction in infectivity [51]. Another report found that activated PBMCs (collected from healthy donors) infected with $\mathrm{HIV}-1_{\mathrm{BAL}}$ in the presence of Velcade and/ or MG-132 exhibited an approximate 10-fold reduction in both viral supernatant reverse transcriptase and proviral copy number in target cells [52]. Finally, three genome-wide knock-down screens, performed to identify cellular modulators of HIV-1 replication, identified the proteasome complex as an enriched gene ontology functional group whose downregulation inhibited HIV-1 replication [69].

The bulk of evidence suggests that the APOBEC3 family of cellular viral restriction factors, among which APOBEC3G and 3F (A3G/F) are the most potent, might explain the PI-induced reduction in virion infectivity observed, especially considering our data indicating that PIs exert their effects only when added to virusproducing cells. A3G/F are cytidine deaminases that have been shown to inhibit HIV-1 infectivity by inducing viral genome hypermutation as well as by causing defects in the efficiency of reverse transcription and integration. In order to inhibit viral infectivity, A3G/F must be expressed in virus-producing cells and packaged into nascent virions. From there, they are able to inhibit viral replication in subsequent target cells (Reviewed in [31]). A3G causes viral genome hypermutation during reverse transcription by deaminating cytidine residues in the minus strand of viral DNA, which results in $\mathrm{G} \rightarrow \mathrm{A} \mathrm{mu-}$ tations in the plus strand of the viral DNA [70-73]. Additionally, A3G was shown to impair primer tRNA processing during reverse transcription, which not only affects the progression of reverse transcription but also results in the creation of viral DNA ends that are unfit for integration into cellular DNA [74-76]. However, under normal conditions, HIV-1 is protected from the effects of A3G/F by the viral protein Vif, which binds to and targets $\mathrm{A} 3 \mathrm{G} / \mathrm{F}$ for proteasomal degradation precluding its incorporation into HIV-1 virions [53,77-81].

Numerous studies have shown that PIs increase intracellular levels of A3G in infected cells by inhibiting its degradation even in the presence of Vif $[53,77-79,81]$. One study found that A3G was incorporated into virions produced from MG-132 treated virus-producing 293T cells and those virions exhibited an approximate 5-fold reduction in infectivity [53]. A3G/F are expressed in primary $\mathrm{CD}^{+} \mathrm{T}$ cells and OM-10.1 cells [31], both of which were used to produce virus during treatment with 
PIs in this study. Therefore, it is a strong possibility that the PI-mediated inhibition of HIV-1 infectivity observed here was in large measure mediated by A3G/F. Explanations for the mechanism through which PIs reduce viral titers might involve the stabilization of TETHERIN, an extracytosolic membrane protein known to inhibit viral release (Reviewed in [30]) or the dysregulation of HIV-1 p6 ${ }^{\mathrm{Gag}}$, known to promote viral budding and to be regulated via monoubiquitination [51]. It will be interesting to delineate these mechanisms, as well as potential alternative mechanism(s) of PI-mediated inhibition of HIV-1 replication in future studies.

Overall, the data presented in this report validate the concept that effective inhibition of both HIV-1 latency and replication is attainable through the use of a single drug. The importance of this is underlined by evidence of differential antiretroviral drug efficacy within viral pools in secondary lymphoid tissue compartments in patients. For instance, a study observed only mild viral inhibition in the secondary lymphoid tissues of patients on ART regimens made up of two or three reverse transcriptase inhibitors [82]. Also, macrophages have been shown to require the highest therapeutic concentrations of protease inhibitors attainable in vivo to inhibit virus production in humans [83]. Moreover, macrophages have been shown to harbor latent HIV-1 in sanctuary tissues, such as the brain [10,17-21], that can be impervious to at least some antiretroviral drugs. For instance, differences in the development of drug resistance between viral isolates from the blood and isolates from the cerebrospinal fluid in patients on HAART indicate that antiretroviral drug penetration into the CNS is not sufficient [22]. Many antiretroviral drugs do not effectively penetrate the BBB [22-28]. The testes represent another potential sanctuary site from which latently infected cells have been isolated $[83,84]$ but in which the blood-testes barrier restricts the entry of some antiretroviral drugs $[83,85]$. Therefore, tissues that are poorly penetrated by antiretroviral drugs represent potential sites in which reactivated latent virus might infect new cells and re-seed the latent reservoir. In fact, viral replication in patients resulting in more than $50 \mathrm{HIV}-1$ RNA copies/ml of blood plasma has been shown to decrease the decay rate of the latent reservoir $[86,87]$. Consequently, in the effort to eliminate latent infection in patients, it is imperative to not only deliver latency antagonists and antiretroviral drugs simultaneously, but to deliver them to the same tissue and cellular compartments. Hence, the development of a single, bifunctional antagonist of both HIV-1 latency and replication is ideal.

Fundamentally, this concept can be applied to the future development of innovative anti-HIV-1 pharmaceuticals capable of clearing latent virus. It is not limited to the use of PIs, as one can imagine employing combinatorial chemistry between different HIV-1 latency activators and replication inhibitors to create novel classes of bifunctional HIV-1 antagonists. However, a PI may very well be a viable option for evaluating the efficacy of an HIV-1 bifunctional antagonist in patients. As previously mentioned, Velcade is already approved by the FDA for the treatment of multiple myeloma and another PI, Marizomib, is currently being evaluated in clinical trials for the treatment of patients with lymphomas, leukemias, and multiple myeloma [37,39]. The most common adverse effects associated with Velcade include gastrointestinal effects, fatigue, thrombocytopenia, and peripheral neuropathy, with the latter two being the most clinically significant $[41,42]$. However, thrombocytopenia was found to wane between cycles of treatment with Velcade [42] and peripheral neuropathy was found to be effectively managed with dose changes [40]. Perhaps even more promising, early phase I clinical trial results with Marizomib have revealed that at less than half the dose of Velcade, Marizomib is more effective and far less toxic. Importantly, Marizomib is characterized by a very small size that allows it to pass the BBB [37], which could be quite important in purging the latent reservoir in patients. Thus, PIs have exhibited substantial efficacies and manageable toxicities in patients with multiple myeloma and therefore, PIs could be considered feasible candidates for an assessment of the efficacy of HIV-1 bifunctional antagonists in infected patients. Also, PIs target a cellular factor, which significantly increases the genetic threshold for the development of drug resistance.

\section{Conclusions}

In this study, PIs are shown to represent a new class of HIV-1 latency antagonists. Additionally, by confirming their anti-replication activity, it is determined that PIs can act as bifunctional antagonists of HIV-1 latency and replication. Therefore, the findings demonstrate the feasibility of developing effective dual-acting inhibitors of HIV-1. This is a novel concept that can be applied to the development of pioneering anti-HIV-1 pharmaceuticals with the potential to substantially impact the goal of purging HIV-1 from infected individuals.

\section{Methods}

\section{Plasmid constructs}

The construct present in HeLa\#14 cells (RLUC/RFP) is an

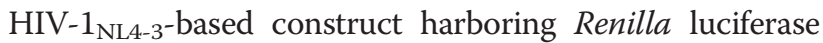
(RLUC) in the env position and red fluorescence protein (RFP) in the nef position [43]. The construct present in 24ST1NLESG cells (SEAP/GFP) is an HIV-1 $1_{\text {NL4-3 }}$-based construct harboring secreted alkaline phosphatase (SEAP) in the env position and green fluorescence protein (GFP) in the nef position [44]. Both the RLUC/RFP and the SEAP/GFP constructs have a 2.5 -kb deletion in pol and a 
1.0-kb deletion in env to render the vectors replicationincompetent. Additionally, the $v p u$ start codon in both constructs is mutated for robust marker gene expression $[43,44]$. The BCL2 expression vector pEB-FLV [46] was a kind gift from Dr. Robert F. Siliciano. The gGn $\Delta$ construct is an $\mathrm{HIV}-1_{\mathrm{NL4}-3-}$ based construct that is replicationincompetent. PCR fragments containing the 3 ' region of env, the complete coding sequence for Gaussia luciferase (GLUC), the T2A sequence, the complete coding sequence for enhanced green fluorescence protein (EGFP), and the $5^{\prime}$ region of nef were fused together by SOEing PCR. The T2A sequence directs bicistronic expression $[88,89]$. The fused PCR fragment was inserted into the HIV $-1_{\text {NL4-3 }}$ construct via BamHI-XhoI restriction sites. A 903-bp deletion in env was made by inserting a PCR fragment, containing the 3 ' region of $v p r$ including a mutation in the start codon of env (ATG $\rightarrow$ ACG) and the 5' region of env up to position 6344, into the HIV-1 $1_{\mathrm{NL4}-3}$ construct via EcoRI-NheI restriction sites. The Gn construct is an $\mathrm{HIV}-1_{\mathrm{NL} 4-3}$-based construct that is replicationcompetent. PCR fragments containing the 3 ' region of env, the complete coding sequence for EGFP, the T2A sequence, and the $5^{\prime}$ region of $n e f$ were fused together by SOEing PCR. The T2A sequence directs bicistronic expression $[88,89]$. The fused PCR fragment was inserted into the $\mathrm{HIV}-1_{\mathrm{NL} 4-3}$ construct via $\mathrm{BamH} 1-\mathrm{Xho} 1$ restriction sites.

\section{Cells and culture media}

The following cell lines were obtained through the AIDS Research and Reference Reagent Program, Division of AIDS, NIAID, NIH: OM-10.1 from Dr. Salvatore Butera [32-36], and U373-MAGI-CXCR4 ${ }_{\text {CEM }}$ from Dr. Michael Emerman [55]. OM-10.1 cells, primary human activated $\mathrm{CD}^{+}{ }^{+} \mathrm{T}$ cells, primary human resting $\mathrm{CD} 4^{+} \mathrm{T}$ cells, primary human $\mathrm{CD}^{+} \mathrm{T}_{\mathrm{CM}^{-}}$-like cells, and primary human $\mathrm{CD}^{+}{ }^{+}$BCL2-transduced cells were cultured in RPMI 1640 GlutaMAX, HEPES medium (Life Technologies, Grand Island, NY) supplemented with 10\% FBS (Thermo Scientific Hyclone, Logan, UT), 2X MEM Non-essential amino acids solution (Life Technologies, Grand Island, $\mathrm{NY}$ ), and $100 \mathrm{U} / \mathrm{ml}$ penicillin- $100 \mu \mathrm{g} / \mathrm{ml}$ streptomycin solution (Life Technologies, Grand Island, NY). HeLa\#14 cells were cultured in MEM GlutaMAX medium (Life Technologies, Grand Island, NY) supplemented with 10\% FetalClone III Serum (Thermo Scientific Hyclone, Logan, UT), 2X MEM Non-essential amino acids solution, and $100 \mathrm{U} / \mathrm{ml}$ penicillin-100 $\mu \mathrm{g} / \mathrm{ml}$ streptomycin solution. U373-MAGI-CXCR4 $4_{\text {CEM }}$ cells were cultured in DMEM, high glucose GlutaMAX medium (Life Technologies, Grand Island, NY) supplemented with 10\% FBS, 2X MEM Non-essential amino acids solution, $0.2 \mathrm{mg} / \mathrm{ml} \mathrm{G418}$ (Sigma-Aldrich, St. Louis, MO), $0.1 \mathrm{mg} / \mathrm{ml}$ hygromycin B (Sigma-Aldrich, St. Louis, MO), and $1.0 \mu \mathrm{g} / \mathrm{ml}$ puromycin
(Sigma-Aldrich, St. Louis, MO). HeLaT4 cells and HEK293T cells were cultured in DMEM, high glucose GlutaMAX medium supplemented with 10\% FetalClone III Serum, 2X MEM Non-essential amino acids solution, and $100 \mathrm{U} / \mathrm{ml}$ penicillin-100 $\mu \mathrm{g} / \mathrm{ml}$ streptomycin solution.

\section{Development of latently infected primary human $\mathrm{CD}^{+}$ T cell models: $\mathrm{T}_{\mathrm{CM}}$-like cells and $B C L 2$-transduced cells} Leukocyte enriched blood samples from healthy adult human donors were purchased from the New York Blood Center. To obtain a purified population of peripheral blood mononuclear cells (PBMCs), buffy coats were isolated from the blood by a Ficoll gradient using Histopaque-1077 (Sigma-Aldrich, St. Louis, MO). Also, red blood cells were lysed using ACK lysing buffer (Lonza, Inc., Allendale, NJ). Primary human $\mathrm{CD}^{+} \mathrm{T}_{\mathrm{CM}^{-}}$ like cells were prepared as previously described [45] with the modification that naive $\mathrm{CD} 4^{+} \mathrm{T}$ cells were separated from PBMCs using the Dynabeads Untouched ${ }^{\mathrm{TM}}$ Human $\mathrm{CD}^{+}{ }^{+} \mathrm{T}$ Cells kit (Life Technologies, Grand Island, NY) according to the manufacturer's instructions with the additional antibodies mouse IgG anti-human CD25 (BD Biosciences, Franklin Lakes, NJ) and mouse IgG antihuman CD45RO (BD Biosciences, Franklin Lakes, NJ) for the specific removal of activated and memory $\mathrm{CD} 4^{+}$ $T$ cells, respectively. Primary human BCL2-transduced $\mathrm{CD}^{+} \mathrm{T}$ cells were prepared as previously described [46] with the modification that cells were activated using the Dynabeads Human T-Activator CD3/CD28 kit (Life Technologies, Grand Island, NY). Vesicular stomatitis virus envelope pseudotyped virions used to establish a latent viral infection in $\mathrm{T}_{\mathrm{CM}}$-like cells or in BCL2-transduced cells were produced in HEK293T cells transfected with the gGn $\Delta$ construct and the packaging plasmid pMD.G [90] using polyethyleneimine linear (molecular weight of $25 \mathrm{kDa}$ ) (Polysciences Inc., Warrington, PA). Forty-eight hours post-transfection, viral supernatants were collected and concentrated 50X using Retro-Concentin (System Biosciences, Mountain View, CA) according to the manufacturer's instructions. $\mathrm{T}_{\mathrm{CM}}$-like cells or BCL2-transduced cells were infected via spinoculation as previously described [91] with the modifications that infections were carried out in 24-well plates and in the presence of $8 \mu \mathrm{g} /$ $\mathrm{ml}$ polybrene (Sigma-Aldrich, St. Louis, MO). Infected cells were cultured for seven days to establish a latent infection $[45,46]$.

\section{Proteasome function assay}

OM-10.1 cells were plated in 12 -well plates at $1 \times 10^{6}$ cells per well. Immediately, cells were treated in duplicate with $1 \mathrm{nM}, 15 \mathrm{nM}$, and $30 \mathrm{nM}$ Velcade (concentration dependence) (Selleckchem, Houston, TX), $5 \mu \mathrm{M}$ clasto-Lactacystin $\beta$-lactone (CLBL) (Sigma-Aldrich, St. Louis, MO), 500 nM MG-132 (Cayman Chemicals, Ann 
Arbor, MI), or $0.25 \%$ DMSO or were left untreated (negative controls). Two hours post-treatment, $1 \times 10^{4}$ cells from each treatment were collected and proteasome function was measured using the Proteasome-Glo Chymotrypsin-Like Cell-Based Assay (Promega, Madison, WI) according to the manufacturer's instructions. Luminescence was measured on the Turner Biosystems 20/20 Luminometer using default settings.

\section{PI treatment to analyze activation of latent HIV-1 transcription}

For the time course experiment, OM-10.1 cells were plated in 12 -well plates at $1 \times 10^{6}$ cells per well. Immediately, cells were treated with $15 \mathrm{nM}$ Velcade, $2 \mu \mathrm{M}$ suberoylanilide hydroxamic acid (SAHA) (Selleckchem, Houston, TX) (positive control), or $0.25 \%$ DMSO (negative control). At the indicated time points, total RNA was isolated from cells using TRIzol Reagent (Life Technologies, Grand Island, NY) according to the manufacturer's instructions. RNA samples were then treated with RQ1 DNase (Promega, Madison, WI) according to the manufacturer's instructions. Reverse transcription PCR was performed to convert RNA to cDNA using the High-Capacity cDNA Reverse Transcription Kit employing random primers (Applied Biosystems (ABI), Foster City, CA) according to the manufacturer's instructions. The cDNA was then used as a template for quantitative PCR (qPCR) to determine HIV-1 $1_{\mathrm{LAV}}$ nef RNA expression levels. The qPCR reactions contained Power Sybergreen PCR Master Mix (ABI, Foster City, CA) and one of the following primer sets: the nef primer set (Forward 5' AAGGGAAAGAATGAGACGAGC-3' and Reverse $5^{\prime}$ GCTACTTGTGATTGCTCCATG-3'), or the GAPDH (reference gene) primer set (Forward 5'-AATCCCAT CACCATCTTCCAG-3' and Reverse 5'-CTTCTCCATG GTGGTGAAGAC-3'). qPCR was performed using the BioRad CFX 96 Real-Time System C1000 Thermal Cycler with the following program settings: $95^{\circ} \mathrm{C}$ for 10 minutes, followed by 40 cycles of $95^{\circ} \mathrm{C}$ for 15 seconds, $60^{\circ} \mathrm{C}$ for 30 seconds, followed by a melt curve. RNA expression was calculated via $\Delta \Delta \mathrm{C}(\mathrm{t})$ method with the values normalized to the expression level of GAPDH in each sample.

For the other RNA experiments, OM-10.1 cells were plated in 12 -well plates at $1 \times 10^{6}$ cells per well. Immediately, cells were treated in duplicate with $1 \mathrm{nM}, 15 \mathrm{nM}$, and $30 \mathrm{nM}$ Velcade (concentration dependence), $5 \mu \mathrm{M}$ CLBL, 500 nM MG-132, $2 \mu \mathrm{M}$ SAHA (positive control), or $0.25 \%$ DMSO (negative control). Seventy-two hours post-treatment, total RNA was isolated, treated with DNase, and reverse transcribed as described above. The cDNA was then used as a template for qPCR to determine $\mathrm{HIV}-1_{\mathrm{LAV}}$ nef and env RNA expression levels. qPCR was performed as described above with the addition of the env primer set (Forward $5^{\prime}$-GCTTTG TTCCTTGGGTTCTTG-3' and Reverse 5' -ATAATTGT CTGGCCTGTACCG-3').

\section{PI treatment to analyze activation of latent HIV-1 gene expression}

Twenty-four hours prior to treatment, HeLa\#14 cells were seeded in 24-well plates at $5 \times 10^{4}$ cells per well. Cells were then treated in triplicate with $4.5 \mu \mathrm{M}$ CLBL, 450 nM MG-132, 7 nM Velcade, $2 \mu$ M SAHA (positive control), or $0.25 \%$ DMSO (negative control). Forty-eight hours post-treatment, the cells were lysed, protein concentration was measured via standard Bradford assay (Bio-Rad Laboratories, Hercules, CA) and RLUC activity was measured using the Renilla luciferase Assay System (Promega, Madison, WI) according to the manufacturer's instructions. Luminescence was measured on the Turner Biosystems 20/20 ${ }^{\text {n }}$ Luminometer with a $10 \mathrm{sec}-$ ond integration setting.

24ST1NLESG cells were plated in 24-well plates at $5 \times 10^{5}$ cells per well. Immediately, cells were treated in triplicate with $4.5 \mu \mathrm{M}$ CLBL, $450 \mathrm{nM}$ MG-132, $7 \mathrm{nM}$ Velcade, $2 \mu \mathrm{M}$ SAHA (positive control), or $0.25 \%$ DMSO (negative control). CLBL and SAHA treated cells were analyzed 48 hours post-treatment while MG-132, Velcade, and DMSO treated cells were analyzed 72 hours post-treatment. The number of live cells in each sample was determined via standard trypan blue exclusion test and quantification using a hemocytometer. SEAP activity in the culture supernatant was measured using the Phospha-Light Secreted Alkaline Phosphatase Reporter Gene Assay System (ABI, Foster City, CA) according to the manufacturer's instructions. Luminescence was measured on the Turner Biosystems 20/20 ${ }^{\text {n }}$ Luminometer using default settings.

OM-10.1 cells were plated in 6 -well plates at $2.5 \times 10^{6}$ cells per well. Immediately, cells were treated in duplicate with $5 \mu \mathrm{M}$ CLBL, $500 \mathrm{nM}$ MG-132, $1 \mathrm{nM}, 15 \mathrm{nM}$, and $30 \mathrm{nM}$ Velcade (concentration dependence), $2 \mu \mathrm{M}$ SAHA (positive control), or $0.25 \%$ DMSO (negative control). Seventy-two hours post-treatment, HIV-1 capsid protein (p24) concentration in the culture supernatant was analyzed via p24 ELISA using the HIV-1 p24 Antigen Capture Kit (AIDS \& Cancer Virus Program, NCI-Frederick, MD) according to their instructions. Secondary antibody peroxidase activity was determined via colorimetric analysis using the Coulter Microplate Reader set to read at $450 \mathrm{~nm}$ with a reference reading at $650 \mathrm{~nm}$.

$\mathrm{T}_{\mathrm{CM}}$-like cells and BCL2-transduced cells, latently infected with the gGn $\Delta$ construct, were plated in 96-well plates at $1 \times 10^{5}$ cells per well. Immediately, cells were treated in singlicate with $5 \mu \mathrm{M}$ CLBL, $250 \mathrm{nM}$ MG-132, 10 nM Velcade, Dynabeads Human T-Activator CD3/ 
CD28 beads according to the manufacturer's instructions in the presence of $30 \mathrm{U} / \mathrm{ml} \mathrm{IL-2} \mathrm{(positive} \mathrm{control),} \mathrm{or} \mathrm{were}$ left untreated (negative control). All cells were simultaneously treated with $10 \mu \mathrm{M}$ Raltegravir to prevent the integration of as yet unintegrated viral genomes. Forty-eight hours post-treatment, cells were fixed with a $1 \%$ formaldehyde solution for 5 minutes and then GFP mean channel fluorescence values were determined using the BD Biosciences Accuri C6 Flow Cytometer set to count $2 \times 10^{3}$ cells per sample.

\section{PI treatment to analyze T cell activation status}

Human PBMCs were isolated from healthy donor leukocyte enriched blood samples as described above. $\mathrm{CD} 4^{+} \mathrm{T}$ cells were isolated using the Dynabeads Untouched ${ }^{\text {ma }}$ Human $\mathrm{CD}^{+}{ }^{+} \mathrm{T}$ Cells kit according to the manufacturer's instructions. The cells were plated in a 96-well plate at $1 \times 10^{5}$ cells per well and then, in singlicate, left untreated (negative control), treated with $10 \mathrm{nM}$ Velcade, treated with $500 \mathrm{nM}$ MG-132, or activated using the Dynabeads Human T-Activator CD3/CD28 kit according to the manufacturer's instructions in the presence of $30 \mathrm{U} / \mathrm{ml} \mathrm{IL-2}$ (positive control). Forty-eight hours post-treatment, cells were incubated with $20 \mu \mathrm{l}$ of mouse IgG FITC-conjugated anti-human CD25 antibody (BD Biosciences, Franklin Lakes, NJ) for 30 minutes at $4^{\circ} \mathrm{C}$. The percentage of $\mathrm{CD} 25^{+}$ cells in each of the samples was then determined using the BD Biosciences Accuri C6 Flow Cytometer set to count $2 \times 10^{3}$ cells per sample.

\section{PI treatment to analyze antagonism of HIV-1 infectivity}

Human PBMCs were isolated from healthy donor leukocyte enriched blood samples as described above. $\mathrm{CD} 4^{+} \mathrm{T}$ cells were isolated using the Dynabeads Untouched ${ }^{\mathrm{mx}}$ Human $\mathrm{CD}^{+} \mathrm{T}$ Cells kit according to the manufacturer's instructions. The $\mathrm{CD}_{4}^{+} \mathrm{T}$ cells were then activated using the Dynabeads Human T-Activator CD3/ CD28 kit according to the manufacturer's instructions in the presence of $30 \mathrm{U} / \mathrm{ml} \mathrm{IL}-2$ and were cultured an additional 3 days in the presence of IL-2. The cells were then plated in 24 -well plates at $2 \times 10^{6}$ cells per well. Immediately, $0.5 \mathrm{ml}$ of $\mathrm{Gn}$ virus stock was added to each well and the cells were spinoculated as previously described [91] in the presence of $8 \mu \mathrm{g} / \mathrm{ml}$ polybrene. Six hours post-spinoculation, the infections were terminated and either $10 \mathrm{nM}$ Velcade was added to the cultures immediately, or the cultures were left untreated as a positive control. Seventy-two hours post-treatment, viral supernatants were collected and p24 concentrations were measured via p24 ELISA using the HIV-1 p24 Antigen Capture Kit according to their instructions. Secondary antibody peroxidase activity was determined via colorimetric analysis using the Coulter Microplate Reader set to read at $450 \mathrm{~nm}$ with a reference reading at
$650 \mathrm{~nm}$. HeLaT4 cells were seeded in 24-well plates at $2 \times 10^{5}$ cells per well 24 hours prior to infection. Viral supernatants were diluted 2.5-fold and then $0.5 \mathrm{ml}$ of diluted supernatants were added to each well in duplicate. As a control for the potential effects arising from residual PI in the inoculums collected from PI-treated $\mathrm{CD}^{+}{ }^{+} \mathrm{T}$ cells, $10 \mathrm{nM}$ Velcade was added to some HeLaT4 cells as they were infected with viral supernatant collected from untreated $\mathrm{CD} 4^{+} \mathrm{T}$ cells. The HeLaT4 cells were then spinoculated in the presence of polybrene as described above. Infections were terminated 6 hours post-spinoculation. Forty-eight hours post-infection, cells were trypsinized and fixed with a $1 \%$ formaldehyde solution for 5 minutes and the percentage of $\mathrm{GFP}^{+}$cells were analyzed using the BD Biosciences Accuri C6 Flow Cytometer set to count $2 \times 10^{3}$ cells per sample.

\section{PI treatment to analyze dual antagonism of HIV-1 latency and replication}

OM-10.1 cells were treated with either $50 \mathrm{ng} / \mathrm{ml} \mathrm{TNF} \alpha$ (Sigma-Aldrich, St. Louis, MO), to stimulate the production of positive control viral particles, or with $5 \mu \mathrm{M}$ CLBL, to stimulate the production of viral particles under the influence of proteasomal inhibition. Seventytwo hours post-treatment, virus-containing supernatants were collected and p24 concentrations were measured via p24. ELISA using the HIV-1 p24. Antigen Capture Kit according to their instructions. Secondary antibody peroxidase activity was determined via colorimetric analysis using the Coulter Microplate Reader set to read at 450 $\mathrm{nm}$ with a reference reading at $650 \mathrm{~nm}$. Twenty-four hours prior to infection, U373-MAGI-CXCR4 $4_{\text {CEM }}$ cells were seeded in 12 -well plates at $1 \times 10^{5}$ cells per well. Viral supernatants were diluted to a p24 concentration of $200 \mathrm{ng} / \mathrm{ml}$ and then $300 \mu \mathrm{l}$ of the diluted viral supernatants were used to infect U373-MAGI-CXCR4 $4_{\text {CEM }}$ cells in duplicate in the presence of $8 \mu \mathrm{g} / \mathrm{ml}$ polybrene at $37^{\circ} \mathrm{C}$. Infections were terminated within 5 hours. Forty-eight hours post-infection, cells were lysed, protein concentration was measured via standard Bradford assay and $\beta$-galactosidase activity was measured using the $\beta$ Galactosidase Enzyme Assay System with Reporter Lysis Buffer (Promega, Madison, WI) according to the manufacturer's instructions. Colorimetric analysis was performed using the Nanodrop 2000 Spectrophotometer set to read at $420 \mathrm{~nm}$.

\section{Abbreviations}

AIDS: Acquired immunodeficiency syndrome; A3G/F: APOBEC3G/APOBEC3F; APOBEC3: Apolipoprotein B mRNA-editing, enzyme-catalytic, polypeptide-like 3; ART: Antiretroviral therapy; $\beta$-gal: Beta-galactosidase; BBB: Blood-brain barrier; BCL2: B-cell lymphoma 2; CDNA: Complementary deoxyribonucleic acid; CLBL: Clasto-Lactacystin beta-lactone; CNS: Central nervous system; CXCR4: Chemokine (C-X-C motif) receptor 4; DMSO: Dimethyl sulfoxide; DNA: Deoxyribonucleic acid; EGFP: Enhanced green fluorescence protein; 
ELISA: Enzyme-linked immunosorbent assay; Env: Envelope; FBS: Fetal bovine serum; FDA: Food and drug administration; FITC: Fluorescein isothiocyanate; GAPDH: Glyceraldehyde 3-phosphate dehydrogenase; GFP: Green fluorescence protein; GLUC: Gaussia luciferase; HAART: Highly active antiretroviral therapy; HIV-1: Human immunodeficiency virus type $1 ; I_{50}$ : Half-maximal inhibitory concentration; IgG: Immunoglobulin G; LTR: Long terminal repeat; LUC: Luciferase; MCF: Mean channel fluorescence; MHC: Major histocompatibility complex; NCl: National cancer institute; Nef: Negative factor: NIAID: National institute of allergy and infectious diseases; NIH: National institutes of health; NFKB: Nuclear factor kappa-light-chain-enhancer of activated B cells; P-TEFb: Positive transcription elongation factor b; p24: HIV-1 capsid protein; PBMC: Peripheral blood mononuclear cell; PCR: Polymerase chain reaction; PI: Proteasome inhibitor; Pol: Polymerase; qPCR: Quantitative polymerase chain reaction; Rev: Regulator of expression of virion proteins; RFP: Red fluorescence protein; RLU: Relative light unit; RLUC: Renilla luciferase; RNA: Ribonucleic acid; SAHA: Suberoylanilide hydroxamic acid; SEAP: Secreted alkaline phosphatase; SEM: Standard error of the mean; SOEing PCR: Synthesis by overlap extension polymerase chain reaction; Tat: Trans-activator of transcription; TNFa: Tumor necrosis factor alpha; tRNA: Transfer ribonucleic acid; Vif: Virion infectivity factor; Vpr: Viral protein R; Vpu: Viral protein U.

\section{Competing interests}

The author(s) declare that they have no competing interests.

\section{Authors' contributions}

LKM designed and performed the majority of the experiments, analyzed the data, and wrote the paper. YK designed and performed experiments involving primary human $\mathrm{CD} 4^{+} \mathrm{T}$ cells. JPD envisioned the overall concept of the study and participated in the drafting of the manuscript. CCC, TAR, and YR, contributed to the conception and design of the study. All authors read and approved this manuscript.

\section{Authors' information}

LKM and TAR are graduate students in the Graduate School of Biomedical Sciences at Rutgers University-Robert Wood Johnson Medical School. YK is a research teaching specialist IV in the department of Pharmacology at Rutgers University-Robert Wood Johnson Medical School. CCC is an adjunct assistant professor in the department of Pharmacology at Rutgers University-Robert Wood Johnson Medical School. YR and JPD are professors in the department of Pharmacology at Rutgers University-Robert Wood Johnson Medical School.

\section{Acknowledgments}

We thank the AIDS Research and Reference Reagent Program, Division of AIDS, NIAID, NIH for providing the OM-10.1 and the U373-MAGI-CXCR4 CEM cell lines. We also thank Dr. Robert F. Siliciano for his generous gift of the pEB-FLV plasmid. Additionally, we thank Dr. James S. Novak for figure design editing.

This work was supported by the grants Al070039, Al081307, and

2T32AI007403-16A2 from the National Institutes of Health.

\section{Received: 3 July 2013 Accepted: 14 October 2013}

Published: 24 October 2013

\section{References}

1. Finzi D, Blankson J, Siliciano JD, Margolick JB, Chadwick K, Pierson T, Smith K, Lisziewicz J, Lori F, Flexner C, et al: Latent infection of CD4+ T cells provides a mechanism for lifelong persistence of HIV-1, even in patients on effective combination therapy. Nat Med 1999, 5:512-517.

2. Choudhary SK, Margolis DM: Curing HIV: Pharmacologic approaches to target HIV-1 latency. Annu Rev Pharmacol Toxicol 2011, 51:397-418.

3. INSPIRE: Interim data released from inspire study on interleukin-7. AIDS Patient Care STDs 2009, 23:987-988.

4. Lehrman G, Hogue IB, Palmer S, Jennings C, Spina CA, Wiegand A, Landay AL, Coombs RW, Richman DD, Mellors JW, et al: Depletion of latent HIV-1 infection in vivo: a proof-of-concept study. Lancet 2005, 366:549-555.

5. Sagot-Lerolle N, Lamine A, Chaix ML, Boufassa F, Aboulker JP, Costagliola D, Goujard C, Pallier C, Delfraissy JF, Lambotte O: Prolonged valproic acid treatment does not reduce the size of latent HIV reservoir. AIDS 2008, 22:1125-1129
6. Sereti I, Dunham RM, Spritzler J, Aga E, Proschan MA, Medvik K, Battaglia CA, Landay AL, Pahwa S, Fischl MA, et al: IL-7 administration drives T cell-cycle entry and expansion in HIV-1 infection. Blood 2009, 113:6304-6314.

7. Siliciano JD, Lai J, Callender M, Pitt E, Zhang H, Margolick JB, Gallant JE, Cofrancesco J Jr, Moore RD, Gange SJ, Siliciano RF: Stability of the latent reservoir for HIV-1 in patients receiving valproic acid. J Infect Dis 2007, 195:833-836.

8. Stellbrink HJ, van Lunzen J, Westby M, O'Sullivan E, Schneider C, Adam A, Weitner L, Kuhlmann B, Hoffmann C, Fenske S, et al: Effects of interleukin-2 plus highly active antiretroviral therapy on HIV-1 replication and proviral DNA (COSMIC trial). AIDS 2002, 16:1479-1487.

9. Lassen $\mathrm{K}$, Han Y, Zhou Y, Siliciano J, Siliciano RF: The multifactorial nature of HIV-1 latency. Trends Mol Med 2004, 10:525-531.

10. Cannon P, Kim SH, Ulich C, Kim S: Analysis of Tat function in human immunodeficiency virus type 1-infected low-level-expression cell lines U1 and ACH-2. J Virol 1994, 68:1993-1997.

11. Carter CC, Onafuwa-Nuga A, McNamara LA, Riddell JT, Bixby D, Savona MR, Collins KL: HIV-1 infects multipotent progenitor cells causing cell death and establishing latent cellular reservoirs. Nat Med 2010, 446:451.

12. Chun TW, Davey RT Jr, Ostrowski M, Shawn JJ, Engel D, Mullins JI, Fauci AS: Relationship between pre-existing viral reservoirs and the re-emergence of plasma viremia after discontinuation of highly active anti-retroviral therapy. Nat Med 2000, 6:757-761.

13. Igarashi T, Brown CR, Endo Y, Buckler-White A, Plishka R, Bischofberger N, Hirsch V, Martin MA: Macrophage are the principal reservoir and sustain high virus loads in rhesus macaques after the depletion of CD4+ T cells by a highly pathogenic simian immunodeficiency virus/HIV type 1 chimera (SHIV): Implications for HIV-1 infections of humans. Proc Natl Acad Sci USA 2001, 98:658-663.

14. McNamara LA, Collins KL: Hematopoietic stem/precursor cells as HIV reservoirs. Curr Opin HIV AIDS 2011, 6:43-48.

15. Siliciano RF: What Do We need to Do to cure HIV infection? Top HIV Med 2010, 18:104-108.

16. Sundstrom JB, Little DM, Villinger $F$, Ellis JE, Ansari AA: Signaling through Toll-like receptors triggers HIV-1 replication in latently infected mast cells. J Immunol 2004, 172:4391-4401.

17. Thompson KA, Cherry CL, Bell JE, McLean CA: Brain cell reservoirs of latent virus in presymptomatic HIV-infected individuals. Am J Pathol 2011, 179:1623-1629.

18. Jones $G$, Power $C$ : Regulation of neural cell survival by HIV-1 infection. Neurobiol Dis 2006, 21:1-17.

19. Nottet HSLM, Persidsky Y, Sasseville VG, Nukuna AN, Bock P, Zhai Q, Sharer $L R$, McComb RD, Swindells S, Soderland C, Gendelman HE: Mechanisms for the transendothelial migration of HIV-1-infected monocytes into brain. J Immunol 1996, 156:1284-1295.

20. Roberts TK, Buckner CM, Berman JW: Leukocyte transmigration across the blood-brain barrier: perspectives on neuroAIDS. Front Biosci (Landmark Ed) 2010, 15:478-536.

21. Williams KC, Corey S, Westmoreland SV, Pauley D, Knight H, deBakker C, Alvarez X, Lackner AA: Perivascular macrophages are the primary cell type productively infected by simian immunodeficiency virus in the brains of macaques: implications for the neuropathogenesis of AIDS. J Exp Med 2001, 193:905-915.

22. Antinori A, Perno CF, Giancola ML, Forbici F, Ippolito G, Hoetelmans RM, Piscitelli SC: Efficacy of cerebrospinal fluid (CSF)-penetrating antiretroviral drugs against HIV in the neurological compartment: different patterns of phenotypic resistance in CSF and plasma. Clin Infect Dis 2005, 41:1787-1793.

23. Ene L, Duiculescu D, Ruta SM: How much do antiretroviral drugs penetrate into the central nervous system? J Med Life 2011, 4:432-439.

24. Enting RH, Hoetelmans MW, Lange JMA, Burger DM, Beijnen JH, Portegies $P$ : Antiretroviral drugs and the central nervous system. AIDS 1998, 12:1941-1955.

25. Foudraine NA, Hoetelmans RMW, Lange JMA, de Wolf F, van Benthem BHB, Maas JJ, Keet IPM, Portegies P: Cerebrospinal-fluid HIV-1RNA and drug concentrations after treatment with lamivudine plus zidovudine or stavudine. Lancet 1998, 351:1547-1551.

26. Groothuis DR, Levy RM: The entry of antiviral and antiretroviral drugs into the central nervous system. J Neurovirol 1997, 3:387-400.

27. Letendre SL, van den Brande G, Hermes A, Woods SP, Durelle J, Beck JM, McCutchan JA, Okamoto C, Ellis RJ: Lopinavr with ritonavir reduces the HIV RNA level in cerebrospinal fluid. Clin Infect Dis 2007, 45:1511-1517. 
28. Marra CM, Lockhart D, Zunt JR, Perrin M, Coombs RW, Collier AC: Changes in CSF and plasma HIV-1 RNA and cognition after starting potent antiretroviral therapy. Neurology 2003, 60:1388-1390.

29. Coux O, Tanaka K, Goldberg AL: Structure and functions of the $20 \mathrm{~S}$ and $26 \mathrm{~S}$ proteasomes. Annu Rev Biochem 1996, 65:801-847.

30. Malim MH, Emerman M: HIV-1 accessory proteins-ensuring viral survival in a hostile environment. Cell Host Microbe 2008, 3:388-398.

31. Wissing S, Galloway NL, Greene WC: HIV-1 Vif versus the APOBEC3 cytidine deaminases: an intracellular duel between pathogen and host restriction factors. Mol Aspects Med 2010, 31:383-397.

32. Butera ST, Perez VL, Besansky NJ, Chan WC, Wu BY, Nabel GJ, Folks TM: Extrachromosomal human immunodeficiency virus type-1 DNA can initiate a spreading infection of HL-60 cells. J Cell Biochem 1991, 45:366-373.

33. Butera ST, Perez VL, Wu BY, Nabel GJ, Folks TM: Oscillation of the human immunodeficiency virus surface receptor is regulated by the state of viral activation in a CD4+ cell model of chronic infection. J Virol 1991, 65:4645-4653.

34. Butera ST, Roberts BD, Folks TM: Regulation of HIV-1 expression by cytokine networks in a CD4+ model of chronic infection. J Immunol 1993, 150:625-634.

35. Butera ST, Roberts BD, Lam L, Hodge T, Folks TM: Human immunodeficiency virus type 1 RNA expression by four chronically infected cell lines indicates multiple mechanisms of latency. J Virol 1994 68:2726-2730

36. Butera ST, Roberts BD, Leung K, Nabel GJ, Folks TM: Tumor necrosis factor receptor expression and signal transduction in HIV-1-infected cells. AIDS 1993, 7:911-918.

37. Huber EM, Groll M: Inhibitors for the immuno- and constitutive proteasome: current and future trends in drug development. Angew Chem Int Ed 2012, 51:8708-8720.

38. Lee $\mathrm{DH}$, Goldberg AL: Proteasome inhibitors: valuable new tools for cell biologists. Trends Cell Biol 1998, 8:397-403.

39. Fenical W, Jensen PR, Palladino MA, Lam KS, Lloyd GK, Potts BC: Discovery and development of the anticancer agent salinosporamide A (NPI-0052). Bioorg Med Chem 2009, 17:2175-2180.

40. Moreau P, Richardson PG, Cavo M, Orlowski RZ, San Miguel JF, Palumbo A Harousseau JL: Proteasome inhibitors in multiple myeloma: 10 years later. Blood 2012, 120:947-959.

41. Richardson PG, Barlogie B, Berenson J, Singhal S, Jagannath S, Irwin D, Rajkumar SV, Srkalovic G, Alsina M, Alexanian R, et al: A phase 2 study of bortezomib in relapsed, refractory myeloma. N Engl J Med 2003, 348:2609-2617.

42. Richardson PG, Sonneveld P, Schuster MW, Irwin D, Stadtmauer EA, Facon T, Harousseau JL, Ben-Yehuda D, Lonial S, Goldschmidt H, et al: Bortezomib or high-dose dexamethasone for relapsed multiple myeloma. N Engl J Med 2005, 352:2487-2498.

43. Edelstein LC, Micheva-Viteva S, Phelan BD, Dougherty JP: Short communication: activation of latent HIV type 1 gene expression by suberoylanilide hydroxamic acid (SAHA), an HDAC inhibitor approved for Use to treat cutaneous T cell lymphoma. AIDS Res Hum Retroviruses 2009, 25:883-887.

44. Micheva-Viteva S, Pacchia AL, Ron Y, Peltz SW, Dougherty JP: Human immunodeficiency virus type 1 latency model for high-throughput screening. Antimicrob Agents Chemother 2005, 49:5185-5188.

45. Bosque A, Planelles V: Studies of HIV-1 latency in an ex vivo model that uses primary central memory T cells. Methods 2011, 53:54-61.

46. Yang HC, Xing S, Shan L, O'Connell K, Dinoso J, Shen A, Zhou Y, Shrum CK, Han Y, Liu JO, et al: Small-molecule screening using a human primary cell model of HIV latency identifies compounds that reverse latency without cellular activation. J Clin Invest 2009, 119:3473-3486.

47. Wang $X$, Luo $H$, Chen $H$, Duguid W, Wu J: Role of proteasomes in T cell activation and proliferation. J Immunol 1998, 160:788-801.

48. Zollner TM, Podda M, Pien C, Elliott PJ, Kaufmann R, Boehncke WH: Proteasome inhibition reduces superantigen-mediated $T$ cell activation and the severity of psoriasis in a SCID-hu model. J Clin Invest 2002, 109:671-679.

49. Goffinet C, Allespach I, Homann S, Tervo HM, Habermann A, Rupp D, Oberbremer L, Kern C, Tibroni N, Welsch S, et al: HIV-1 antagonism of CD317 is species specific and involves Vpu-mediated proteasomal degradation of the restriction factor. Cell Host Microbe 2009, 5:285-297.

50. Gupta RK, Hue S, Schaller T, Verschoor E, Pillay D, Towers GJ: Mutation of a single residue renders human tetherin resistant to HIV-1 Vpu-mediated depletion. PLoS Pathog 2009, 5:e1000443.
51. Schubert U, Ott DE, Chertova EN, Welker R, Tessmer U, Princiotta MF, Bennink JR, Krausslich $\mathrm{H}$, Yewdell JW: Proteasome inhibition interferes with Gag polyprotein processing, release, and maturation of HIV-1 and HIV-2. PNAS 2000, 97:13057-13062.

52. Yu L, Mohanram V, Simonson OE, Smith CIE, Spetz A, Mohamed AJ: Proteasome inhibitors block HIV-1 replication by affecting both cellular and viral targets. Biochem Biophys Res Commun 2009, 385:100-105.

53. Yu X, Yu Y, Liu B, Luo K, Kong W, Mao P, Yu XF: Induction of APOBEC3G ubiquitination and degradation by an HIV-1 Vif-Cul5-SCF complex. Science 2003, 302:1056-1060.

54. Schwartz O, Marechal V, Friguet B, Arenzana-Seisdedos F, Heard JM: Antiviral activity of the proteasome on incoming human immunodeficiency virus type 1. J Virol 1998, 72:3845-3850

55. Vodicka MA, Goh WC, Wu LI, Rogel ME, Bartz SR, Schweickart VL, Raport CJ, Emerman M: Indicator cell lines for detection of primary strains of human and simian immunodeficiency viruses. Virology 1997, 233:193-198.

56. Stevens M, De Clercq E, Balzarini J: The regulation of HIV-1 transcription: molecular targets for chemotherapeutic intervention. Med Res Rev 2006, 26:595-625.

57. Krishnan V, Zeichner SL: Host cell gene expression during human immunodeficiency virus type 1 latency and reactivation and effects of targeting genes that are differentially expressed in viral latency. J Virol 2004, 78:9458-9473.

58. Olivares I, Ballester A, Lombardia L, Dominguez O, Lopez-Galindez C: Human immunodeficiency virus type 1 chronic infection is associated with different gene expression in MT-4, H9 and U937 cell lines. Virus Res 2009, 139:22-31.

59. Anzinger JJ, Olinger GG, Spear GT: Donor variability in HIV binding to peripheral blood mononuclear cells. Virol J 2008, 5:95

60. Stoddart MJ, Richards RG, Alini M: In vitro experiments with primary mammalian cells: to pool or not to pool? Eur Cell Mater 2012, 24:i-ii.

61. Archin NM, Eron JJ, Palmer S, Hartmann-Duff A, Martinson JA, Wiegand A, Bandarenko N, Schmitz JL, Bosch RJ, Landay AL, et al: Valproic acid without intensified antiviral therapy has limited impact on persistent HIV infection of resting CD4+ T cells. AIDS 2008, 22:1131-1135.

62. Archin NM, Keedy KS, Espeseth A, Dang H, Hazuda DJ, Margolis DM: Expression of latent human immunodeficiency type 1 is induced by novel and selective histone deacetylase inhibitors. AIDS 2009, 23:1799-1806.

63. Archin NM, Espeseth A, Parker D, Cheema M, Hazuda D, Margolis DM: Expression of latent HIV induced by the potent HDAC inhibitor suberoylanilide hydroxamic acid. AIDS Res Hum Retroviruses 2009, 25:207-212.

64. Ylisastigui L, Archin NM, Lehrman G, Bosch RJ, Margolis DM: Coaxing HIV-1 from resting CD4 T cells: histone deacetylase inhibition allows latent viral expression. AIDS 2004, 18:1101-1108

65. Collins GA, Tansey WP: The proteasome: a utility tool for transcription? Curr Opin Genet Dev 2006, 16:197-202.

66. Lassot I, Latreille D, Rousset E, Sourisseau M, Linares LK, Chable-Bessia C, Coux O, Benkirane M, Kiernan RE: The proteasome regulates HIV-1 transcription by both proteolytic and nonproteolytic mechanisms. Mol Cell 2007, 25:369-383.

67. Nakamura M, Basavarajaiah P, Rousset E, Beraud C, Latreille D, Henaoui I Lassot I, Mari B, Kiernan RE: Spt6 levels are modulated by PAAF1 and proteasome to regulate the HIV-1 LTR. Retrovirology 2012, 9:13.

68. Budhiraja S, Famiglietti M, Bosque A, Planelles V, Rice AP: Cyclin T1 and CDK9 T-loop phosphorylation Are downregulated during establishment of HIV-1 latency in primary resting memory CD4+ T cells. J Virol 2013, 87:1211-1220

69. Bushman FD, Malani N, Fernandes J, D'Orso I, Cagney G, Diamond TL, Zhou H, Hazuda DJ, Espeseth AS, Konig R, et al: Host cell factors in HIV replication: meta-analysis of genome-wide studies. PLOS Pathog 2009, 5:e1000437.

70. Harris RS, Bishop KN, Sheehy AM, Craig HM, Petersen-Mahrt SK, Watt IN, Neuberger MS, Malim MH: DNA deamination mediates innate immunity to retroviral infection. Cell 2003, 113:803-809.

71. KewalRamani VN, Coffin JM: Weapons of mutational destruction. Science 2003, 301:923-925

72. Mangeat B, Turelli P, Caron G, Friedli M, Perrin L, Trono D: Broad antiretroviral defence by human APOBEC3G through lethal editing of nascent reverse transcripts. Nature 2003, 424:99-103.

73. Zhang H, Yang B, Pomerantz RJ, Zhang C, Arunachalam SC, Gao L: The cytidine deaminase CEM15 induces hypermutation in newly synthesized HIV-1 DNA. Nature 2003, 424:94-98. 
74. Klarmann GJ, Chen X, North TW, Preston BD: Incorporation of uracil into minus strand DNA affects the specificity of plus strand sunthesis initiation during lentiviral reverse transcription. J Biol Chem 2003, 278:7902-7909.

75. Mbisa JL, Barr R, Thomas JA, Vandegraaff N, Dorweiler IJ, Svarovskaia ES, Brown WL, Mansky LM, Gorelick RJ, Harris RS, et al: Human immunodeficiency virus type $1 \mathrm{cDNAs}$ produced in the presence of APOBEC3G exhibit defects in plus-strand DNA transfer and integration. J Virol 2007, 81:7099-7110.

76. Mbisa JL, Bu W, Pathak VK: APOBEC3F and APOBEC3G inhibit HIV-1 DNA integration by different mechanisms. J Virol 2010, 84:5250-5259.

77. Conticello SG, Harris RS, Neuberger MS: The Vif protein of HIV triggers degradation of the human antiretroviral DNA deaminase APOBEC3G. Curr Biol 2003, 13:2009-2013.

78. Marin M, Rose KM, Kozak SL, Kabat D: HIV-1 Vif protein binds the editing enzyme APOBEC3G and induces its degradation. Nat Med 2003, 9:1398-1403.

79. Sheehy AM, Gaddis NC, Malim MH: The antiretroviral enzyme APOBEC3G is degraded by the proteasome in response to HIV-1 Vif. Nat Med 2003, 9:1404-1407.

80. Simon $\mathrm{JH}$, Malim MH: The human immunodeficiency virus type $1 \mathrm{Vif}$ protein modulates the postpenetration stability of viral nucleoprotein complexes. J Virol 1996, 70:5297-5305.

81. Stopak K, de Noronha C, Yonemoto W, Greene WC: HIV-1 Vif blocks the antiviral activity of APOBEC3G by impairing both its translation and intracellular stability. Mol Cell 2003, 12:591-601.

82. Cavert W, Notermans DW, Staskus K, Wietgrefe SW, Zupancic M, Gebhard K, Henry K, Zhang Z, Mills R, McDade H, et al: Kinetics of response in lymphoid tissues to antiretroviral therapy of HIV-1 infection. Science 1997, 276:960-964.

83. Schrager LK, D'Souza MP: Cellular and anatomical reservoirs of HIV-1 in patients receiving potent antiretroviral combination therapy. JAMA 1998, 280:67-71.

84. Zhang H, Geethanjali D, Beumont M, Livornese L, van Uitert B, Henning K, Pomerantz RJ: Human immunodeficiency virus type 1 in the semen of Men receiving highly active antiretroviral therapy. N Engl J Med 1998, 339:1803-1809.

85. Di Mascio M, Srinivasula S, Bhattacharjee A, Cheng L, Martiniova L, Herscovitch P, Lertora J, Kiesewetter D: Antiretroviral tissue kinetics: in vivo imaging using positron emission tomography. Antimicrob Agents Chemother 2009, 53:4086-4095.

86. Jones LE, Perelson AS: Transient viremia, plasma viral load, and reservoir replenishment in HIV-infected patients on antiretroviral therapy. J Acquir Immune Defic Syndr 2007, 45:483-493.

87. Martinez-Picado J, DePasquale MP, Kartsonis N, Hanna GJ, Wong J, Finzi D, Rosenberg E, Gunthard HF, Sutton L, Savara A, et al: Antiretroviral resistance during successful therapy of HIV type 1 infection. Proc Natl Acad Sci USA 2000, 97:10948-10953.

88. Donnelly ML, Luke G, Mehrotra A, Li X, Hughes LE, Gani D, Ryan MD: Analysis of the aphthovirus $2 \mathrm{~A} / 2 \mathrm{~B}$ polyprotein 'cleavage' mechanism indicates not a proteolytic reaction, but a novel translational effect: a putative ribosomal 'skip'. J Gen Virol 2001, 82:1013-1025.

89. Ryan MD, King AMQ, Thomas GP: Cleavage of foot-and-mouth disease virus polyprotein is mediated by residues located within a 19 amino acid sequence. J Gen Virol 1991, 72:2727-2732.

90. Ory DS, Neugeboren BA, Mulligan RC: A stable human-derived packaging cell line for production of high titer retrovirus/vesicular stomatitis virus G pseudotypes. Proc Natl Acad Sci USA 1996, 93:11400-11406.

91. O'Doherty U, Swiggard WJ, Malim MH: Human immunodeficiency virus type 1 spinoculation enhances infection through virus binding. J Virol 2000, 74:10074-10080

doi:10.1186/1742-4690-10-120

Cite this article as: Miller et al:: Proteasome inhibitors act as bifunctional antagonists of human immunodeficiency virus type 1 latency and replication. Retrovirology 2013 10:120.

\section{Submit your next manuscript to BioMed Central and take full advantage of:}

- Convenient online submission

- Thorough peer review

- No space constraints or color figure charges

- Immediate publication on acceptance

- Inclusion in PubMed, CAS, Scopus and Google Scholar

- Research which is freely available for redistribution

Submit your manuscript at www.biomedcentral.com/submit
C) BioMed Central 